\title{
Effect of Temperature and Time on Zinc Borate Species Formed from Zinc Oxide and Boric Acid in Aqueous Medium
}

\author{
H. Emre Eltepe, ${ }^{\dagger}$ Devrim Balköse, $*, *$ and Semra Ülkï ${ }^{\ddagger}$ \\ Pigment AŞ Kemalpaşa, Izmir, Turkey, and Department of Chemical Engineering, Izmir Institute of Technology, \\ Gulbahce Koyu, Urla-Izmir 35430, Turkey
}

The effect of temperature and time of heating of zinc oxide and boric acid in aqueous medium on product type, dehydration behavior, crystal morphology, and structure was investigated for the production of flame retardant and smoke suppressant zinc borate. Two different products dehydrated at 140 and $350{ }^{\circ} \mathrm{C}$ were obtained and characterized by thermal gravimetric analysis, X-ray diffraction, energy dispersive spectroscopy, and Fourier transform infrared spectroscopy.

\section{Introduction}

Plastic materials widely used all throughout our lives release smoke and toxic gases during heating at high temperatures. Zinc borates (ZBs) are widely used flame retardants and smoke suppressants. Zinc borates have been used in flame retarding of paints ${ }^{1}$ and EVA. ${ }^{2}$ Giudice and Benitez ${ }^{1}$ discussed the influence of $\mathrm{ZB}$ with molecular formulas containing $3.5 \mathrm{H}_{2} \mathrm{O}$ and $7.5 \mathrm{H}_{2} \mathrm{O}$ on flame resistance of paints. Eight different paint compositions were prepared. Limiting oxygen index (LOI) according to ASTM D 2863 and flame spread index (FSI) tests were carried out to test the flame retardancy. The compositions having both $\mathrm{ZBs}$ and having only $7.5 \mathrm{H}_{2} \mathrm{O}$ with antimony trioxide had the maximum LOI values. The increase in the use of synergistic mixture of zinc borate together with aluminum trihydrate has also increased flame retardency. The reason for this usage is that the synergistic mixture of these two compounds promotes a nonhalogen char formation. ${ }^{1}$ Bourbigot et al. ${ }^{2}$ have studied the recent advances in the use of zinc borate in the flame retardancy of EVA. In their work, zinc borates were used as synergistic agents in ethyl vinyl acetate-aluminum trihydrate (EVA-ATH) and EVA-Mg(OH $)_{2}$ flame retardant formulations and as smoke suppressants. The flame retardancy of low-density polyethylene (LDPE) treated with complex flame retardant composed of ultrafine zinc borate (UZB) and intumescent flame retardant (IFR) was maximum when the mass ratio of UZB to IFR is $4.2: 25.8$, and the complex flame retardant mass content was $30 \%$ (based on LDPE). Boron orthophosphate $\left(\mathrm{BPO}_{4}\right)$ and zinc-containing compounds were formed in the residual char, and these substances may play an important role in stabilizing the intumescent char structure and decreasing the degradation speed substantially when subjected to high temperature. ${ }^{3}$ The study about the effects of zinc borate (ZB), aluminum trihydrate (ATH), and their mixture on the flame-retardant and smokesuppressant properties of poly(vinyl chloride) (PVC) shows that the incorporation of a small amount of $\mathrm{ZB}, \mathrm{ATH}$, and their mixture can greatly increase the LOI of PVC and reduce the smoke density of PVC during combustion. The mixture of ZB with $\mathrm{ATH}$ has a good synergistic effect on the flame retardance and smoke suppression of PVC. Thermal gravimetric analysis

* To whom correspondence should be addressed. Prof. Dr. Devrim Balköse, Faculty of Engineering, Department of Chemical Engineering, Gülbahçeköyü Urla İzmir, Turkey. Tel.: +90 232750 6642. Fax:+90 232750 6645. E-mail address: devrimbalkose@iyte.edu.tr.

† Pigment AŞ Kemalpaşa.

$\doteqdot$ Izmir Institute of Technology.
(TGA) and gas chromatography-mass spectroscopy (GC-MS) analysis results show that the incorporation of a small amount of ZB, ATH, and their mixture greatly promotes the char formation of PVC and decreases the amount of hazardous gases such as benzene and toluene released in PVC during combustion. Zinc borate as a flame retardant formulation on some tropical woods reduced drastically their flame propagation rate, after glow time, and flame temperature and increased their residue (char) and LOI. It was observed that zinc borate acidified with HCI functions as a flame retardant (FR) formulation by a complex process that entails the dehydration and condensed phase and vapor phase mechanisms. ${ }^{5}$

A series of different crystal structures of zinc borate (ZB) have been developed and are being used. The most widely used ones are zinc borate with the formula $3 \mathrm{ZnO} \cdot 2 \mathrm{~B}_{2} \mathrm{O}_{3} \cdot 3.5 \mathrm{H}_{2} \mathrm{O}$, $2 \mathrm{ZnO} \cdot 3 \mathrm{~B}_{2} \mathrm{O}_{3} \cdot 3 \mathrm{H}_{2} \mathrm{O}$, and anhydrous $\mathrm{ZB} 2 \mathrm{ZnO} \cdot 3 \mathrm{~B}_{2} \mathrm{O}_{3}$. The heat stability of zinc borate is between $290-300{ }^{\circ} \mathrm{C}$ which enables the polymer processibility and the heat stability of anhydrous borate up to $400{ }^{\circ} \mathrm{C}$. Zinc borate $2 \mathrm{ZnO} \cdot 3 \mathrm{~B}_{2} \mathrm{O}_{3} \cdot 7 \mathrm{H}_{2} \mathrm{O}$ is formed when borax is added to aqueous solutions of soluble zinc salts at temperatures below about $70{ }^{\circ} \mathrm{C}$. An X-ray structure determination has indicated that this compound is orthorhombic and has a zinc triborate monohydrate structure $\mathrm{Zn}\left[\mathrm{B}_{3} \mathrm{O}_{3}(\mathrm{OH})_{5}\right] \cdot \mathrm{H}_{2} \mathrm{O}$. Zinc borates $2 \mathrm{ZnO} \cdot 3 \mathrm{~B}_{2} \mathrm{O}_{3} \cdot 7 \mathrm{H}_{2} \mathrm{O}$ and $\mathrm{ZnO} \cdot \mathrm{B}_{2} \mathrm{O}_{3} \cdot 2 \mathrm{H}_{2} \mathrm{O}$ release water when heated from 130 to $250{ }^{\circ} \mathrm{C} .6$

Zinc borate $\left(2 \mathrm{ZnO} \cdot 3 \mathrm{~B}_{2} \mathrm{O}_{3} \cdot 3.5 \mathrm{H}_{2} \mathrm{O}\right)$ in general is produced with the reaction between zinc oxide and boric acid. Boric acid is dissolved in water between the temperatures 95 and $98{ }^{\circ} \mathrm{C}$, and zinc oxide and seed crystals of $2 \mathrm{ZnO} \cdot 3 \mathrm{~B}_{2} \mathrm{O}_{3} \cdot 3.5 \mathrm{H}_{2} \mathrm{O}$ is added to this solution at a certain stoichiometric ratio. The reaction continues for a while by mixing, and the zinc borate formed is filtered, dried, and ground. Schubert et al. ${ }^{7}$ found out that $2 \mathrm{ZnO} \cdot 3 \mathrm{~B}_{2} \mathrm{O}_{3} \cdot 3.5 \mathrm{H}_{2} \mathrm{O}$ was actually $\mathrm{Zn}\left[\mathrm{B}_{3} \mathrm{O}_{4}(\mathrm{OH})_{3}\right](\mathrm{ZnO} \cdot$ $3 \mathrm{~B}_{2} \mathrm{O}_{3} \cdot 3 \mathrm{H}_{2} \mathrm{O}$ written in oxide form). The structure of $\mathrm{Zn}\left[\mathrm{B}_{3} \mathrm{O}_{4-}\right.$ $(\mathrm{OH})_{3}$ ] was determined for the first time by single-crystal X-ray diffraction and $\mathrm{H}$ magic angle spinning (MAS) NMR, revealing it to be a complex network consisting of infinite polytriborate chains crosslinked by coordination with zinc and further integrated by hydrogen bonding. The boroxyl oxygen involved in zinc coordination lies between the $\mathrm{BO}_{3}$ and $\mathrm{BO}_{4}$ polyhedra involved in chain extension. The remaining two zinc coordination sites are occupied by hydroxyl oxygens of the $\mathrm{BO}_{2}(\mathrm{OH})_{2}$ groups in two separate polyborate chains. In this way, all hydroxyl groups are involved in zinc coordination. $2 \mathrm{ZnO} \cdot 3 \mathrm{~B}_{2} \mathrm{O}_{3} \cdot$ $3 \mathrm{H}_{2} \mathrm{O}$ hydrolyzes to $\mathrm{ZnO}$ and boric acid in aqueous medium if 
Table 1. pH Change after Mixing $\mathrm{ZnO}$ and Boric Acid at $60{ }^{\circ} \mathrm{C}$

\begin{tabular}{llllllllll}
\hline time (s) & 0 & 10 & 30 & 60 & 120 & 180 & 240 & 360 & 420
\end{tabular}

$\begin{array}{llllllllll}\mathrm{pH} & 4.30 & 5.33 & 5.63 & 5.68 & 5.70 & 5.72 & 5.72 & 5.72 & 5.72\end{array}$

the temperature exceeds $90{ }^{\circ} \mathrm{C}$. Further in the article, the correct formula of $2 \mathrm{ZnO} \cdot 3 \mathrm{~B}_{2} \mathrm{O}_{3} \cdot 3.5 \mathrm{H}_{2} \mathrm{O}$ will be used as $2 \mathrm{ZnO} \cdot 3 \mathrm{~B}_{2} \mathrm{O}_{3}$. $3 \mathrm{H}_{2} \mathrm{O}$.

Nies et al. ${ }^{8}$ developed a method for producing zinc borate with a low hydration number by using sodium borate and zinc salts.

In another patent by Igarashi et al., ${ }^{9}$ zinc borate having a particular crystallite size and containing very little sodium components and a method of preparing the same was studied. The zinc borate had a particular chemical composition, had a crystallite size not smaller than $40 \mathrm{~nm}$ as found from diffraction peaks of indexes of planes of (020), (101), and (200) in the $\mathrm{X}$-ray diffraction image $(\mathrm{Cu} \mathrm{K} \alpha)$, and contained sodium components in amounts not larger than 100 ppm as measured by the atomic absorption spectroscopy. Igarashi et al. ${ }^{9}$ prepared $2 \mathrm{ZnO} \cdot 3 \mathrm{~B}_{2} \mathrm{O}_{3} \cdot 3.0 \mathrm{H}_{2} \mathrm{O}$ from boric acid and zinc oxide in two steps. In the first step at $60{ }^{\circ} \mathrm{C}$ for $1.5 \mathrm{~h}$, zinc borate crystals form, and in the second step at $90{ }^{\circ} \mathrm{C}$ for $4 \mathrm{~h}$, the crystal growth occurs. Schubert et al. ${ }^{7}$ indicated that the formation of $2 \mathrm{ZnO}$ $3 \mathrm{~B}_{2} \mathrm{O}_{3} \cdot 7 \mathrm{H}_{2} \mathrm{O}$ was initially from $\mathrm{ZnO}$ and boric acid and that it is transformed to $2 \mathrm{ZnO} \cdot 3 \mathrm{~B}_{2} \mathrm{O}_{3} \cdot 3 \mathrm{H}_{2} \mathrm{O}$ by slow polymerization of borate ions in the solid state.

In a US patent by Schubert, ${ }^{10}$ zinc borate compositions having a $\mathrm{ZnO}: \mathrm{B}_{2} \mathrm{O}_{3}$ ratio of $4: 1$ and anhydrous zinc borate were examined. The patent relates to improved zinc borate compositions and, more particularly, provides a new hydrated zinc borate having a high dehydration temperature which offers significant advantages for compounding with plastics and rubbers at elevated temperatures. The anhydrous form of zinc borate was also provided in this study, offering advantages for compounding at even high temperatures.

Shete et al. ${ }^{11}$ have studied the kinetics of the fluid-solid reaction of zinc borate by the reaction between zinc oxide and boric acid. Mixing parameters influencing the final particle size and conversion of zinc oxide were studied for the formation of zinc borate. The formation of zinc borate is via a fluid-solid reaction. The process was kinetically controlled above the minimum speed for particle suspension. The reaction kinetics was developed, and the rate constant was estimated in this study. The reaction was assumed to be a first-order surface reaction with respect to boric acid, and rate constants were found from experimental conversion time data. Shete et al. ${ }^{11}$ considered the diffusion of boric acid to $\mathrm{ZnO}$ particles but not the rearrangement of borate rings with time to polyborate ions in their kinetic model.

Thousands of metric tons of this material have been manufactured by several companies around the world for more than 35 years using the reaction of zinc oxide with boric acid. Although zinc borate production has long been a widely known and practiced technology, there is no study of the characterization of intermediates formed. Thus, the effects of time and temperature of heating, seed crystals, and refluxing on the type and properties of zinc borate species obtained from zinc oxide and boric acid in aqueous medium were the aim of investigation in this work.

\section{Experimental}

2.1. Materials. The boric acid supplied by ETIBANK with a molecular weight 61.83 and a molecular formula of $\mathrm{B}(\mathrm{OH})_{3}$ with $99.9 \%$ purity and the zinc oxide (99\%) from Ege Kimya

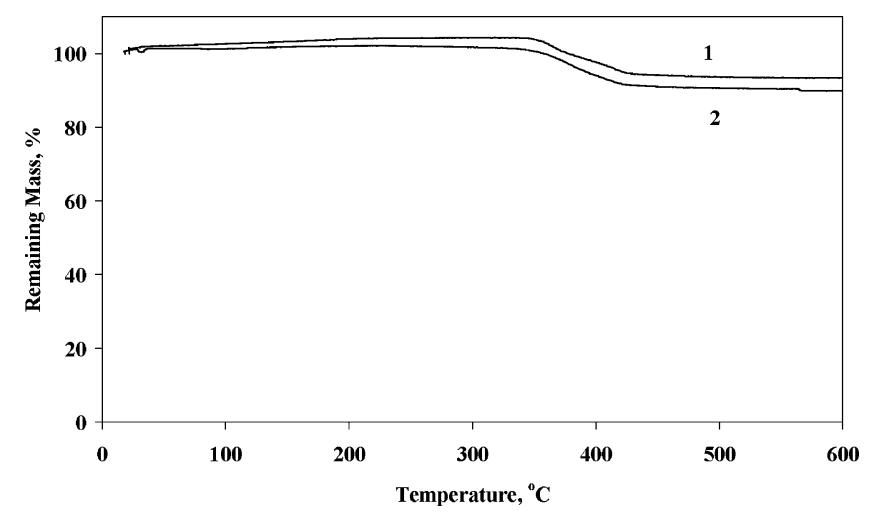

Figure 1. TGA curves of commercial ZB: (1) ZB-2335; (2) Chinese ZB.

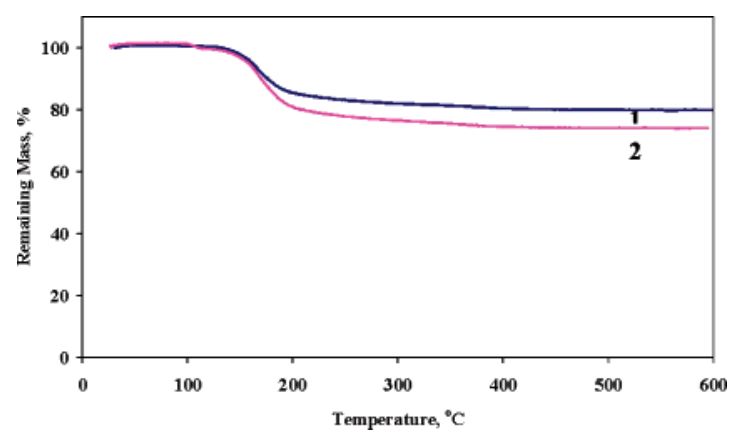

Figure 2. TGA curves of samples prepared at $60^{\circ} \mathrm{C}$ for $90 \mathrm{~min}$ (1) with seed crystal and (2) without seed crystal.

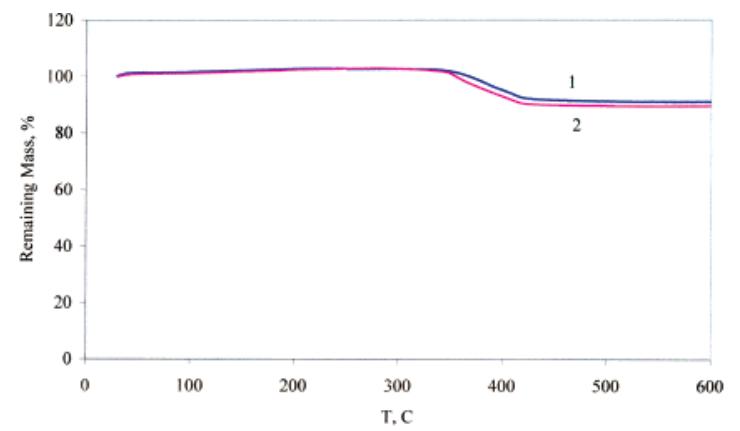

Figure 3. TGA curves of product formed at $90{ }^{\circ} \mathrm{C}$ for $4 \mathrm{~h}$ (1) with seed crystal and (2) without seed crystal (they were heated at $60^{\circ} \mathrm{C}$ for $1.5 \mathrm{~h}$ initially).

were used throughout the experiments. Commercial zinc borates called $\mathrm{ZB}-2335$ with $37 \% \mathrm{ZnO}$ and $47 \% \mathrm{~B}_{2} \mathrm{O}_{3}$ and a maximum of $16 \%$ water of crystallization and Chinese zinc borate with $37.5 \% \mathrm{ZnO}$ and $48 \% \mathrm{~B}_{2} \mathrm{O}_{3}$ and with ignition loss at $400{ }^{\circ} \mathrm{C}$ as a maximum of $14.5 \%$ were used in the experiments as reference materials.

2.1. Methods. The synthesis of $2 \mathrm{ZnO} \cdot 3 \mathrm{~B}_{2} \mathrm{O}_{3} \cdot 3 \mathrm{H}_{2} \mathrm{O}$ was done according to the overall reaction given in eq 1 .

$$
\begin{aligned}
2 \mathrm{ZnO}(\mathrm{s})+6 \mathrm{H}_{3} \mathrm{BO}_{3}(\mathrm{aq}) & \rightarrow \\
& 2 \mathrm{ZnO} \cdot 3 \mathrm{~B}_{2} \mathrm{O}_{3} \cdot 3 \mathrm{H}_{2} \mathrm{O}(\mathrm{s})+6 \mathrm{H}_{2} \mathrm{O}
\end{aligned}
$$

The experiments were carried out by first dissolving the required amount of boric acid in a separate beaker in pure water. Since the solubility of boric acid at room temperature $\left(20^{\circ} \mathrm{C}\right)$ is $5.04 \%$, the solution of $290 \mathrm{~g} / \mathrm{dm}^{3}$ boric acid in water was prepared by heating the mixture at $60{ }^{\circ} \mathrm{C}$. After boric acid was completely dissolved in water, zinc oxide was added to make the concentration $96 \mathrm{~g} / \mathrm{dm}^{3} \mathrm{ZnO}$ in the mixture making the molar molar ratio of $\mathrm{B}_{2} \mathrm{O}_{3}$ to $\mathrm{ZnO}$ be 2 . An excess amount of boric acid was used to ensure the formation of $2 \mathrm{ZnO} \cdot 3 \mathrm{~B}_{2} \mathrm{O}_{3} \cdot 3.0 \mathrm{H}_{2} \mathrm{O}$. 


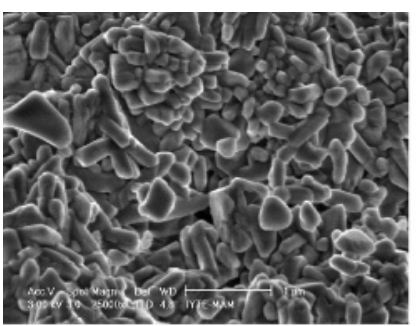

(a)

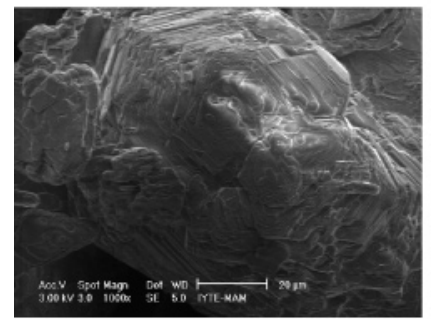

(c)

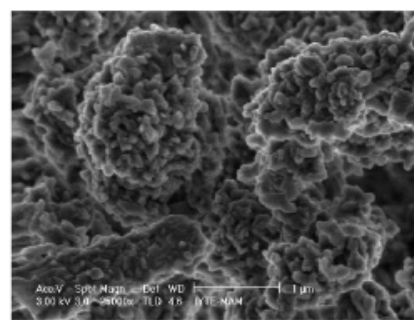

(b)

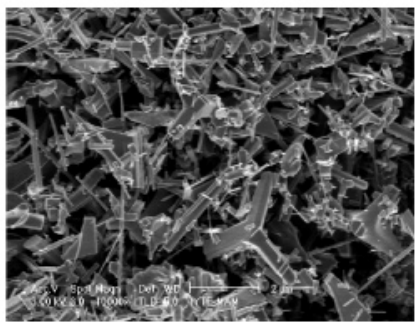

(d)
Figure 4. SEM microphotographs of commercial $\mathrm{ZB}$ and raw materials (a) ZB-2335 $(25000 \times)$, (b) Chinese ZB $(25000 \times)$, (c) Boric acid $(1000 \times)$, and (d) Zinc oxide $(25000 \times)$.

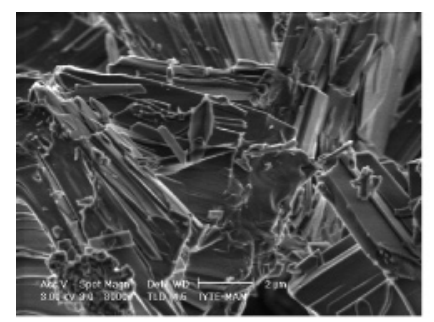

(a)

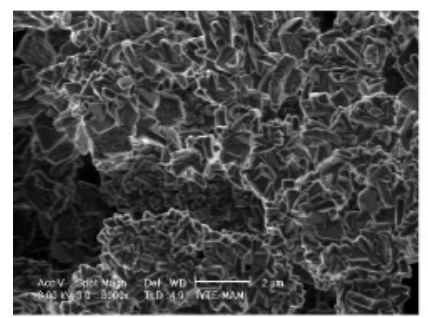

(c)

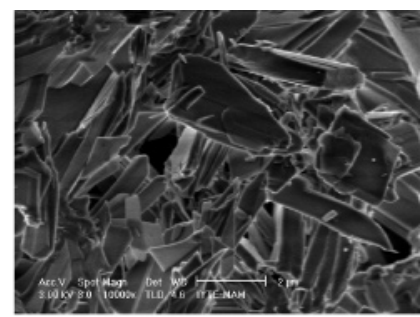

(b)

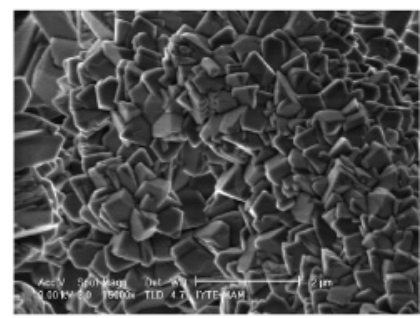

(d)
Figure 5. SEM microphotographs of samples prepared at $60{ }^{\circ} \mathrm{C}$ for $1.5 \mathrm{~h}$ (a) with seed crystals $(8000 \times)$ and (b) without seed crystals $(10000 \times)$ and of samples prepared at $90{ }^{\circ} \mathrm{C}$ for $4 \mathrm{~h}$ (they were heated at $60{ }^{\circ} \mathrm{C}$ for 1.5 h) (c) with seed crystals $(8000 \times)$ and (d) without seed crystals $(15000 \times)$.

A $0.125 \mathrm{~g}$ portion of ZB 2335 was added as seed crystal. This mixture in closed Schott bottles was stirred for $1.5 \mathrm{~h}$ at this temperature in a constant temperature bath. After a small sample was drawn, the mixture was further stirred and reacted at $90{ }^{\circ} \mathrm{C}$ for $4 \mathrm{~h}$. Mixing was achieved by shaking the bottles in a temperature controlled water bath at a rate of $170 \mathrm{rpm}$. The $\mathrm{pH}$ of the mixture was measured by a Methrom $\mathrm{pH}$ meter with a glass electrode from time to time. A second experiment under the same conditions but without any seed crystal was also done. The samples were filtered using a Buchner funnel and dried at $105^{\circ} \mathrm{C}$ for $2 \mathrm{~h}$ in an air circulating oven.

2.2. Characterizations. Each sample was characterized by X-ray diffraction, Fourier transform infrared spectroscopy (FTIR), scanning electron microscopy (SEM), energy dispersive X-ray (EDX) analysis, and thermal gravimetric analysis (TGA). Microstructural characterization of the samples was done by

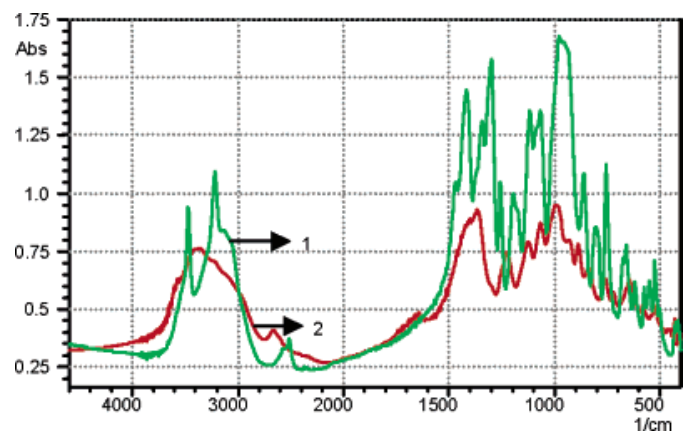

Figure 6. FTIR spectra of (1) ZB-2335 and (2) sample prepared at $60{ }^{\circ} \mathrm{C}$ for $1.5 \mathrm{~h}$ without seed crystal.

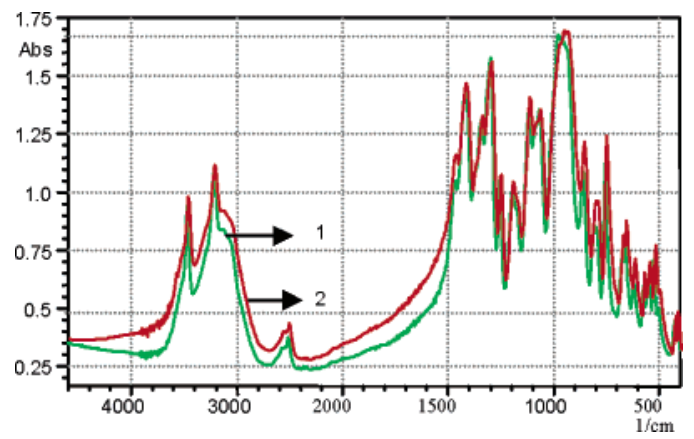

Figure 7. FTIR spectra of (1) ZB-2335 and (2) sample heated at $90{ }^{\circ} \mathrm{C}$ for $4 \mathrm{~h}$ (initially, it was heated at $60{ }^{\circ} \mathrm{C}$ for $1.5 \mathrm{~h}$ ).

Table 2. Properties of Reference Materials and Products Determined by TGA and EDX

\begin{tabular}{cccc}
\hline sample & $\begin{array}{c}\mathrm{H}_{2} \mathrm{O} \text { loss at } \\
600{ }^{\circ} \mathrm{C}(\%)\end{array}$ & $\begin{array}{c}\text { dehydr } \\
\text { onset } T\left({ }^{\circ} \mathbf{C}\right)\end{array}$ & $\begin{array}{c}\mathrm{B}_{2} \mathrm{O}_{3} / \mathrm{ZnO} \\
(\text { molar ratio })\end{array}$ \\
\hline $\begin{array}{l}60{ }^{\circ} \mathrm{C} \text { for } 1.5 \mathrm{~h} \\
\text { with seed crystal }\end{array}$ & 21 & 130 & 1.49 \\
$\begin{array}{l}60^{\circ} \mathrm{C} \text { for } 1.5 \mathrm{~h} \text { and } 90{ }^{\circ} \mathrm{C} \\
\text { for } 4 \mathrm{~h} \text { with seed crystal }\end{array}$ & 10 & 350 & 1.40 \\
$60{ }^{\circ} \mathrm{C}$ for $1.5 \mathrm{~h}$ without \\
$\begin{array}{l}\text { seed crystal } \\
60^{\circ} \mathrm{C} \text { for } 1.5 \mathrm{~h} \text { and } 90^{\circ} \mathrm{C} \\
\text { for } 4 \mathrm{~h} \text { without seed crystal }\end{array}$ & 27 & 131 & 1.78 \\
\end{tabular}

scanning electron microscopy using a Philips XL-305 FEG SEM instrument. The elemental composition of the samples were determined by conducting energy dispersive X-ray (EDX) analysis in the same instrument.

All of the samples were characterized by X-ray diffractometer (Philips Xpert-Pro) to analyze the crystal structures of the ZB with $\mathrm{Cu} \mathrm{K} \alpha$ radiation at $45 \mathrm{kV}$ and $40 \mathrm{~mA}$. The registrations were performed in the $5^{\circ}-60^{\circ} 2 \theta$ range.

Thermal gravimetric analyses (TGAs) were done with a Shimadzu TGA-51. ZB samples $(10-15 \mathrm{mg})$ were loaded into an alumina pan and heated from 30 to $600{ }^{\circ} \mathrm{C}$ at $10{ }^{\circ} \mathrm{C} / \mathrm{min}$ under $\mathrm{N}_{2}$ flow (40 $\left.\mathrm{mL} / \mathrm{min}\right)$.

To determine which functional groups are present in the samples, a Shimadzu FTIR 8601 was used. The $\mathrm{KBr}$ disc method was used by mixing $4.0 \mathrm{mg}$ of $\mathrm{ZB}$ and $196 \mathrm{mg}$ of $\mathrm{KBr}$. A pellet was obtained by pressing the powder mixture under 8 tons of pressure.

\section{Results and Discussion}

3.1. Reactions. The following reactions are expected to occur in zinc borate preparation. Solid boric acid dissolution (eq 2), hydration of $\mathrm{ZnO}$ in water (eq 3), formation of $\mathrm{Zn}\left[\mathrm{B}_{3} \mathrm{O}_{3}(\mathrm{OH})_{5}\right]$. $\mathrm{H}_{2} \mathrm{O}(\mathrm{s})$ at $60{ }^{\circ} \mathrm{C}$ (eq 4), and formation of $\mathrm{Zn}\left[\mathrm{B}_{3} \mathrm{O}_{4}(\mathrm{OH})_{3}\right](\mathrm{s})$ at $90{ }^{\circ} \mathrm{C}$ (eq 5). 


$$
\begin{gathered}
\mathrm{B}(\mathrm{OH})_{3}(\mathrm{~s}) \rightarrow \mathrm{B}(\mathrm{OH})_{3}(\mathrm{aq}) \\
\mathrm{ZnO}(\mathrm{s})+\mathrm{H}_{2} \mathrm{O} \rightarrow \mathrm{Zn}(\mathrm{OH})_{2}(\mathrm{~s}) \\
\mathrm{Zn}(\mathrm{OH})_{2}(\mathrm{~s})+3 \mathrm{~B}(\mathrm{OH})_{3}(\mathrm{aq}) \rightarrow \\
\mathrm{Zn}\left[\mathrm{B}_{3} \mathrm{O}_{3}(\mathrm{OH})_{5}\right] \cdot \mathrm{H}_{2} \mathrm{O}(\mathrm{s})+2 \mathrm{H}_{2} \mathrm{O} \\
\mathrm{Zn}\left[\mathrm{B}_{3} \mathrm{O}_{3}(\mathrm{OH})_{5}\right] \cdot \mathrm{H}_{2} \mathrm{O}(\mathrm{s}) \rightarrow \\
\rightarrow \\
\mathrm{Zn}\left[\mathrm{B}_{3} \mathrm{O}_{4}(\mathrm{OH})_{3}\right](\mathrm{s})+2 \mathrm{H}_{2} \mathrm{O}
\end{gathered}
$$

Since an excess of boric acid was used, the solution $\mathrm{pH}$ is expected to be acidic. In the experimental run to follow $\mathrm{pH}$ change during reaction, it was found that the $\mathrm{pH}$ of the boric acid solution was 4.3 and there was a step change to 5.33 in 10 $\mathrm{s}$ after $\mathrm{ZnO}$ was added as reported in Table 1 . The $\mathrm{pH}$ was stabilized at 5.72 after $180 \mathrm{~s}$, and it did not change with time any more. Thus, during preparation of $\mathrm{ZB}$, the $\mathrm{pH}$ was lower than a $\mathrm{pH}$ of 7 and the reaction medium was acidic as expected. This showed that the neutralization occurred instantly after the addition of $\mathrm{ZnO}$ to boric acid as there was a step change to $\mathrm{pH}$ 5.33 in $10 \mathrm{~s}$. The formed product was not the desired crystal modification of $\mathrm{ZB}$ with $3 \mathrm{~mol}$ water, but it was a form with a higher amount of crystal water. The further mixing of $\mathrm{ZnO}$ and boric acid at $90{ }^{\circ} \mathrm{C}$ for $4 \mathrm{~h}^{4,6,7}$ under reflux would result in a $\mathrm{ZB}$ formation which has the desired chemical formula, $2 \mathrm{ZnO}$ $3 \mathrm{~B}_{2} \mathrm{O}_{3} \cdot 3 \mathrm{H}_{2} \mathrm{O}$, and thus the desired dehydration temperature.

3.2. Mixing Problems. The volume of the solid products in the reaction mixture increases with time, and mixing problems occur due to an increase in viscosity. The specific gravities of $\mathrm{ZnO}$ and $2 \mathrm{ZnO} \cdot 3 \mathrm{~B}_{2} \mathrm{O}_{3} \cdot 3 \mathrm{H}_{2} \mathrm{O}$ are 5.3 and $2.77 \mathrm{~g} / \mathrm{cm}^{3}$, respectively. In the patent by Igarashi et al., ${ }^{9} 1 \mathrm{~L}$ of water contained $290 \mathrm{~g}$ of boric acid and $96 \mathrm{~g}$ of $\mathrm{ZnO}$ while boric acid is present in dissolved form and $\mathrm{ZnO}$ is a solid. The $\mathrm{B}_{2} \mathrm{O}_{3} / \mathrm{ZnO}$ ratio was 2.0 in the reactant mixture, but in the product, it was 1.5. The mass of the solid fraction increases 2.66 times and corresponds to a volume fraction increase of 5.11 times considering the densities. This causes a 4.36-fold increase in the viscosity of the mixture during the beginning and end of the reaction as found using eq 6 .

$$
\eta=\eta_{\mathrm{s}}\left(1+k_{\mathrm{E}} \phi\right)
$$

where $\eta$ is viscosity of the suspension, $\eta_{\mathrm{s}}$ is the viscosity of the solvent, $k_{\mathrm{E}}$ is 2.5 for spherical particles, and $\phi$ is the volume fraction of the dispersed solid phase.

Thus, a mechanical mixer which will stir the mixture even when the viscosity is high should be used for this reaction. In the present study, a temperature controlled water bath was used since a small amount of reactants was in consideration. By using a closed container, water loss by evaporation was prevented. In large scale production, a reactor under reflux and with a very powerful mechanical mixer should be used.

3.3. Characterizations. The physicochemical properties of each sample as well as the reference ZBs were determined by thermal gravimetric analysis (TGA), Fourier transform infrared spectroscopy (FTIR), scanning electron microscopy (SEM), energy dispersive X-ray (EDX) analysis, and X-ray diffraction.

The upward slope of the TGA curves in Figures 1-3 during the initial periods of heating was due to a small drift in the baseline of the instrument. TGA curves of commercial zinc borates in Figure 1 indicated that they were very stable up to $350{ }^{\circ} \mathrm{C}$ and they lost $8 \%$ and $6 \%$ of their mass for ZB 2355 and China $\mathrm{ZB}$, respectively, up to $600{ }^{\circ} \mathrm{C}$. The $2 \mathrm{ZnO} \cdot 3 \mathrm{~B}_{2} \mathrm{O}_{3}$. $3 \mathrm{H}_{2} \mathrm{O}$ has been reported to be thermally stable up to $290{ }^{\circ} \mathrm{C}$ by

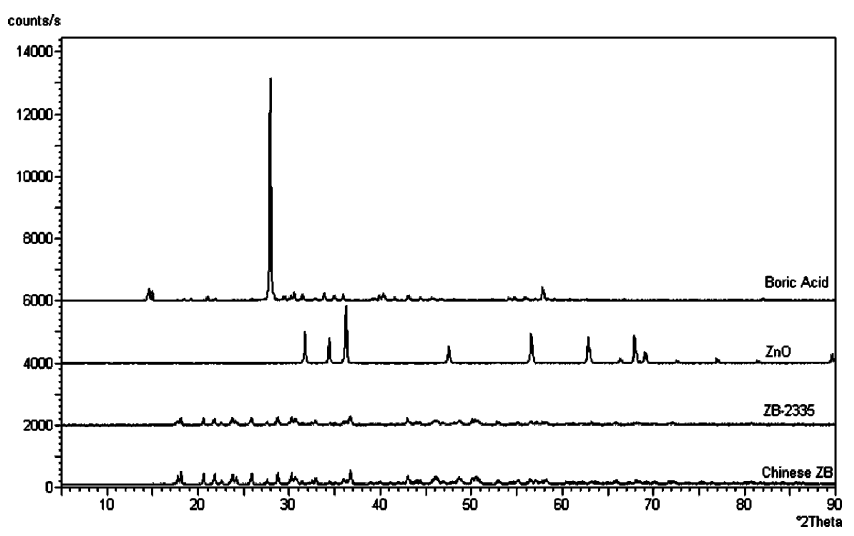

Figure 8. X-ray diffraction diagrams of reference ZB materials and raw materials.

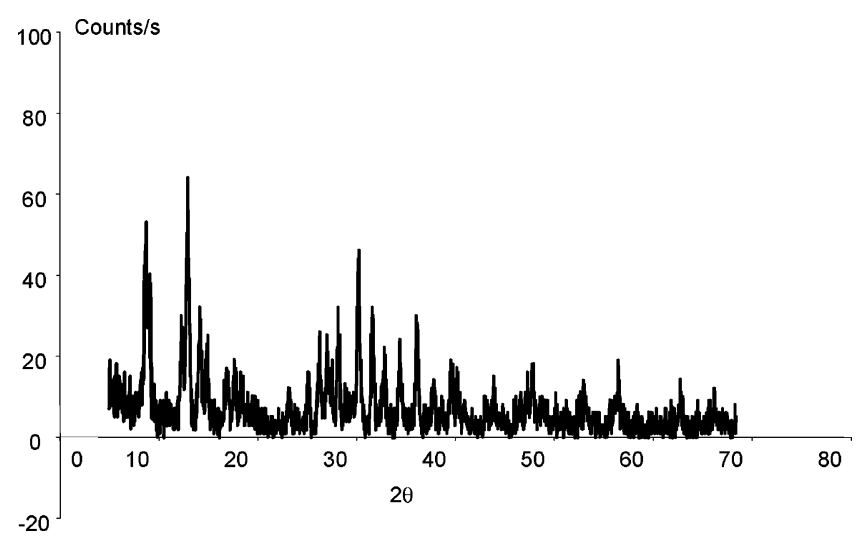

Figure 9. X-ray diffraction diagram of sample prepared at $60{ }^{\circ} \mathrm{C}$ for 1.5 $\mathrm{h}$ without seed crystal.

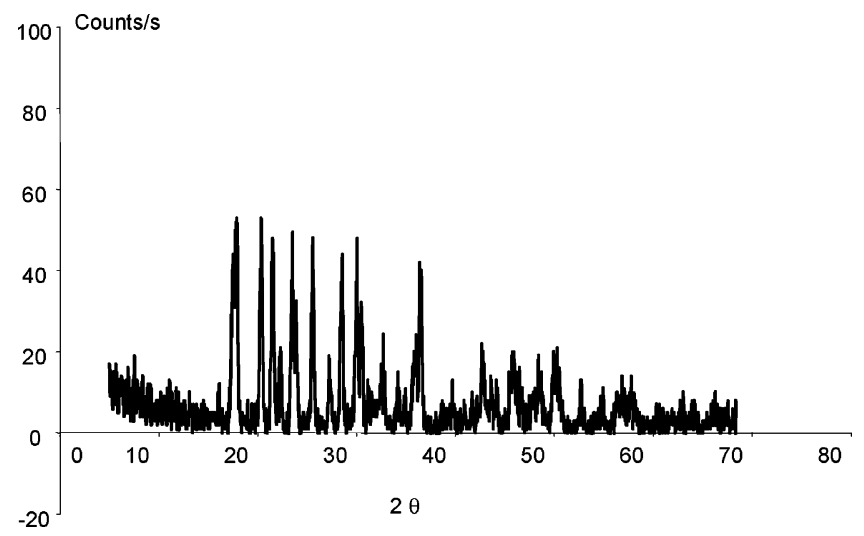

Figure 10. X-ray diffraction diagrams of sample heated at $90{ }^{\circ} \mathrm{C}$ for $4 \mathrm{~h}$ without seed crystal (initially, it was heated at $60^{\circ} \mathrm{C}$ for $1.5 \mathrm{~h}$ ).

Schubert at al. ${ }^{7}$ The dynamic heating program of the TGA analysis should have caused to a shift to higher temperatures in observation of the thermal stability temperature. TGA curves of samples prepared at $60{ }^{\circ} \mathrm{C}$ for $1.5 \mathrm{~h}$ without and with seed crystals are given in Figure 2. For samples prepared at $60{ }^{\circ} \mathrm{C}$ for $1.5 \mathrm{~h}$ with seed crystals, $\mathrm{ZB}$ starts to lose its hydration water at $130^{\circ} \mathrm{C}$ with a mass loss of $21 \%$ until $600{ }^{\circ} \mathrm{C}$, and for samples prepared at $60{ }^{\circ} \mathrm{C}$ for $1.5 \mathrm{~h}$ without seed crystals, ZB starts to lose its mass at $131^{\circ} \mathrm{C}$ with a mass loss of $26 \%$ until $600{ }^{\circ} \mathrm{C}$. When these two samples are compared, it is observed that the one with seed crystals has less mass loss due to dehydration than that without seed crystals. For samples heated further at $90{ }^{\circ} \mathrm{C}$ for $4 \mathrm{~h}$, the mass losses started at 350 and $340{ }^{\circ} \mathrm{C}$ and amounts to $12 \%$ and $10 \%$ at $600{ }^{\circ} \mathrm{C}$ for the samples with and without seed crystals, respectively, as seen in Figure 3. These samples had dehydration temperatures and mass losses very 
Table 3. X-ray Diffraction Peaks of the Samples

\begin{tabular}{ccccc}
\hline \multicolumn{2}{c}{$60^{\circ} \mathrm{C}, 1.5 \mathrm{~h}$} & & \multicolumn{2}{c}{$90^{\circ} \mathrm{C}, 4 \mathrm{~h}$} \\
\cline { 5 - 5 } $\begin{array}{c}\text { with seed } \\
\text { crystals }\end{array}$ & $\begin{array}{c}\text { without seed } \\
\text { crystals }\end{array}$ & & $\begin{array}{c}\text { with seed } \\
\text { crystals }\end{array}$ & $\begin{array}{c}\text { without seed } \\
\text { crystals }\end{array}$ \\
\hline $2 \theta$ & $2 \theta$ & & $2 \theta$ & $2 \theta$ \\
8.0 & 8.0 & & & \\
17.5 & 17.6 & & 17.7 & 17.9 \\
20.8 & 20.4 & & 20.3 & 20.3 \\
23.0 & 22.8 & & 21.4 & 21.6 \\
23.5 & 23.3 & & 23.4 & 23.5 \\
27.4 & 24.0 & & 25.5 & 25.5 \\
28.7 & 27.0 & & 27.2 & 27.2 \\
& 28.1 & & 28.4 & 28.5
\end{tabular}

close to commercial ones. On the other hand, if $2 \mathrm{ZnO} \cdot 3 \mathrm{~B}_{2} \mathrm{O}_{3}$. $3 \mathrm{H}_{2} \mathrm{O}$ were obtained, mass loss should have been $14.9 \%$. The sample prepared without seed crystals at $90^{\circ} \mathrm{C}$ had as a closer mass loss $(12 \%)$ to that of $2 \mathrm{ZnO} \cdot 3 \mathrm{~B}_{2} \mathrm{O}_{3} \cdot 3 \mathrm{H}_{2} \mathrm{O}$. The mass loss values at $600{ }^{\circ} \mathrm{C}$ are reported in Table 2 .

The SEM micrograph of zinc oxide particles in Figure 4 shows that they were in needle shape and were a maximum of $2 \mu \mathrm{m}$ long. Two commercial ZBs had similar morphologies as seen in Figure 4. SEM microphotographs of samples prepared at $60{ }^{\circ} \mathrm{C}$ for $1.5 \mathrm{~h}$ with and without seed crystals were very similar to each other as seen in Figure 5. There were no unreacted $\mathrm{ZnO}$ crystals with needle shape. The samples further heated at $90^{\circ} \mathrm{C}$ for $4 \mathrm{~h}$ had a similar morphology to those which are used as reference products as seen in Figures 4 and 5.

The FTIR spectrum of the sample prepared at $60{ }^{\circ} \mathrm{C}$ for 1.5 $\mathrm{h}$ was different than the FTIR spectrum of commercial ZB 2335 as seen in Figure 6. While the characteristic peak at $3227 \mathrm{~cm}^{-1}$ of $\mathrm{ZnO} \cdot \mathrm{B}_{2} \mathrm{O}_{3}$ crystal structure ${ }^{2}$ is not observed in the sample's spectrum, ZB 2335 had two sharp peaks at 3250 and $3500 \mathrm{~cm}^{-1}$ belonging to vibrations of isolated $\mathrm{OH}$ groups. ${ }^{9}$ In Figure 7 , it is seen that the sample prepared by heating at $90{ }^{\circ} \mathrm{C}$ for $4 \mathrm{~h}$ had the same FTIR spectrum as commercial ZB 2335. The peaks between 900 and $1300 \mathrm{~cm}^{-1}$ are all present in the spectra which were reported to be other characteristic peaks of borates. ${ }^{12}$ The characteristic peaks of tetrahedral $\left(\mathrm{BO}_{4}\right)$ and trihedral $\left(\mathrm{BO}_{3}\right)$ borate groups are clearly seen between 1100 and $800 \mathrm{~cm}^{-1}$ and between 1450 and $1200 \mathrm{~cm}^{-1}$.

The chemical compositions of the samples were determined by EDX analysis as reported in Table 2. While the theoretical $\mathrm{B}_{2} \mathrm{O}_{3} / \mathrm{ZnO}$ ratio was 1.50 for $2 \mathrm{ZnO} \cdot 3 \mathrm{~B}_{2} \mathrm{O}_{3} \cdot 3 \mathrm{H}_{2} \mathrm{O}$, it was 1.40 for samples prepared with seed crystals and it increased to 1.78 and 1.68 for samples prepared without seed crystals. The presence of seed crystals caused the formation of products closer to the $\mathrm{B}_{2} \mathrm{O}_{3} / \mathrm{ZnO}$ ratio in $2 \mathrm{ZnO} \cdot 3 \mathrm{~B}_{2} \mathrm{O}_{3} \cdot 3 \mathrm{H}_{2} \mathrm{O}$.

$\mathrm{X}$-ray diffraction diagrams of raw materials and commercial $\mathrm{ZBs}$ are seen in Figure 8. Boric acid and $\mathrm{ZnO}$ had X-ray diffraction diagrams of pure materials as indicated by the $\mathrm{X}$-pert pro software. Commercial ZBs had the same X-ray diffraction diagram of $2 \mathrm{ZnO} \cdot 3 \mathrm{~B}_{2} \mathrm{O}_{3} \cdot 3 \mathrm{H}_{2} \mathrm{O}$ reported by Igarashi et al. ${ }^{9}$ and Nies et al. ${ }^{8}$ The X-ray diffraction diagrams of the samples prepared at $60^{\circ} \mathrm{C}$ with and without seed crystals were the same. In Figure 9, the X-ray diffraction diagram of a sample prepared at $60{ }^{\circ} \mathrm{C}$ is shown and it has no similarity to the ZB X-ray diffraction diagram reported by Igarashi et al. ${ }^{9}$ A strong diffraction peak at a $2 \theta$ value of $8^{\circ}$ corresponding to $1.11 \mathrm{~nm}$ present in the sample prepared at $60^{\circ} \mathrm{C}$ was not present in the $\mathrm{X}$-ray diffraction diagram of $2 \mathrm{ZnO} \cdot 3 \mathrm{~B}_{2} \mathrm{O}_{3} \cdot 3 \mathrm{H}_{2} \mathrm{O}$ samples pre- pared at $90{ }^{\circ} \mathrm{C}$ for $4 \mathrm{~h}$. The X-ray diffraction diagrams of the samples prepared at $90{ }^{\circ} \mathrm{C}$ in Figure 10 were identical to each other and to that of $2 \mathrm{ZnO} \cdot 3 \mathrm{~B}_{2} \mathrm{O}_{3} \cdot 3 \mathrm{H}_{2} \mathrm{O}$ reported by Igarishi et al. ${ }^{9} \mathrm{X}$-ray diffraction peak intensities of the samples prepared at 60 and $90{ }^{\circ} \mathrm{C}$ are as shown in Table 3.

\section{Conclusions}

Using a powerful mixer and good temperature control and keeping the volume constant by using reflux to prevent water evaporation are important requirements in obtaining the desired zinc borate species, since the viscosity of the medium increases to a great extent during reaction.

Two different zinc borates dehydrating at around $130{ }^{\circ} \mathrm{C}$ with $21-27 \%$ mass loss and at around $350{ }^{\circ} \mathrm{C}$ with $10-12 \%$ mass loss were obtained at $60{ }^{\circ} \mathrm{C}$ and further heating at $90{ }^{\circ} \mathrm{C}$, respectively, from zinc oxide and boric acid in water. They should be $\mathrm{Zn}\left[\mathrm{B}_{3} \mathrm{O}_{3}(\mathrm{OH})_{5}\right] \cdot \mathrm{H}_{2} \mathrm{O}$ or $2 \mathrm{ZnO} \cdot 3 \mathrm{~B}_{2} \mathrm{O}_{3} \cdot 7 \mathrm{H}_{2} \mathrm{O}$ and $\mathrm{Zn}$ $\left[\mathrm{B}_{3} \mathrm{O}_{4}(\mathrm{OH})_{3}\right]$ or $2 \mathrm{ZnO} \cdot 3 \mathrm{~B}_{2} \mathrm{O}_{3} \cdot 3 \mathrm{H}_{2} \mathrm{O}$. The $\mathrm{X}$-ray diffraction diagrams of the samples prepared at $90{ }^{\circ} \mathrm{C}$ with and without seed crystals were identical to that of $2 \mathrm{ZnO} \cdot 3 \mathrm{~B}_{2} \mathrm{O}_{3} \cdot 3 \mathrm{H}_{2} \mathrm{O}$ reported by Igarishi et al., ${ }^{9}$ but their $\mathrm{B}_{2} \mathrm{O}_{3} / \mathrm{ZnO}$ ratios were different than that of $2 \mathrm{ZnO} \cdot 3 \mathrm{~B}_{2} \mathrm{O}_{3} \cdot 3 \mathrm{H}_{2} \mathrm{O}$. Their TGA curves and FTIR spectra were the same as the two commercial zinc borates which are claimed to be $2 \mathrm{ZnO} \cdot 3 \mathrm{~B}_{2} \mathrm{O}_{3} \cdot 3 \mathrm{H}_{2} \mathrm{O}$ by their producers.

\section{Literature Cited}

(1) Giudice, C. A.; Benitez, J. C. Zinc Borates As Flame-retardant Pigments In Chlorine containing Coatings. Prog. Org. Coat. 2001 42, 82.

(2) Bourbigot, S.; Bras, M. L.; Leeuwendal, R.; Shen, K. K.; Schubert, D. Recent Advances In the Use of Zinc Borates In Flame Retardancy of EVA. Polym. Degrad. Stab. 1999, 64, 419.

(3) Wu, Z.; Shu, W.; Hu, Y. Synergist Flame Retarding Effect of Ultrafine Zinc Borate on LDPE/IFR System. Appl. Polym. Sci. 2000, 103, 3667.

(4) Ning, Y.; Gua, S. Flame-Retardant and Smoke-Suppressant Properties of Zinc Borate and Aluminum Trihydrate-Filled Rigid PVC. J. Appl. Polym. Sci. 2000, 77, 3119.

(5) Garba, B. Effect of zinc borate as flame retardant formulation on some tropical woods. Polym. Degrad. Stab. 1998, 40.

(6) Kirk-Othmer Encyclopedia of Chemical Technology, 4th ed.; John, Wiley and Sons: New York, 1994; Vols. 10 and 4.

(7) Schubert, D. M.; Alam, F.; Mandana, Z. V.; Knobler, C. Structural Characterization and Chemistry of The Industrially Important Zinc Borate, $\mathrm{Zn}\left[\mathrm{B}_{3} \mathrm{O}_{4}(\mathrm{OH})_{3}\right]$. Chem. Mater. 2003, 15, 866.

(8) Nies, N. P.; Beach, L.; Hulbert, R. W. Zinc Borate with low hydration and method for preparing the same. US Patent No. 3,649,172, 1972.

(9) Igarashi, H.; Tatebe, A.; Sakao, K. Zinc Borate, and Production Method and Use Thereof. EP Patent No. 1,205,439A1, 2001.

(10) Schubert, D. M. Zinc Borate. US Patent No. 5,472,644, 1995.

(11) Shete, A. V.; Sawant, S. B.; Pangarkar, V. G. Kinetics of FluidSolid Reaction With An Insoluble Product: Zinc Borate By The Reaction of Boric Acid and Zinc Oxide. J. Chem. Technol. Biotechnol. 2003, 79, 526.

(12) Yongzhong, J.; Shiyang, G.; Shuping, X.; Jun, L. FT-IR spectroscopy of supersaturated aqueous solutions of magnesium borate. Spectrochim Acta Part A 1999, 56, 1291

(13) Xie, R.; Qu, B.; Hu, K. Dynamic FTIR Studies of Thermo Oxidation of Expandable Graphite-based Halogen-free Flame Retardant LLDPE Blends. Polym. Degrad. Stab. 2001, 72, 313.

Received for review August 4, 2006 Revised manuscript received February 2, 2007 Accepted February 7, 2007

IE0610243 